\title{
Erratum
}

\section{Witchcraft, Shamanism, and Nostalgia. A Review Essay-ERRATUM}

doi: 10.1017/S0010417515000638. Published online by Cambridge University Press, 20 January 2016

\section{PETER GESCHIERE}

University of Amsterdam

Due to an editorial error in the January 2016 issue of Comparative Studies in Society and History, Peter Geschiere's affiliation was incorrectly listed as Arizona State University. His affiliation is University of Amsterdam. In footnote 2, Michael Ostling's affiliation should have been changed from University of Queensland to Arizona State University.

We regret the error.

\section{REFERENCE}

Geschiere, Peter. 2016. Witchcraft, Shamanism, and Nostalgia. A Review Essay. Comparative Studies in Society and History 58, 1: 242-65. doi:10.1017/ S0010417515000638. 